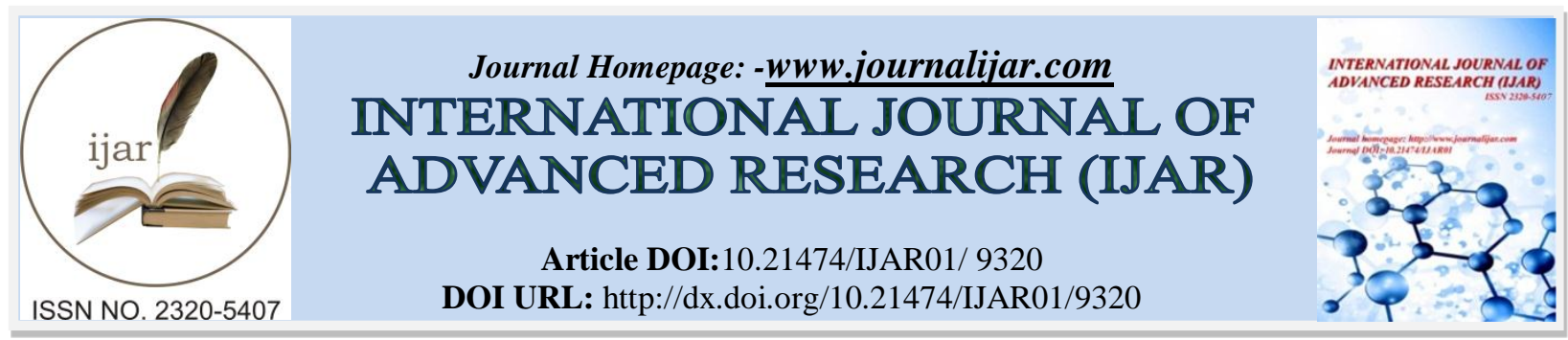

RESEARCH ARTICLE

\title{
REDUCING ESCHERICHIA COLI CONTAMINATION ON DRINGKING WATER STATIONS IN PASURUAN, EAST JAVA, INDONESIA.
}

\author{
Wiwik Winarningsih ${ }^{1}$, Z.Fanani ${ }^{2}$, Endah Setyowati ${ }^{2}$ and Jack Rubijoso ${ }^{2}$. \\ 1. Postgraduate student of environmental science, brawijaya university. \\ 2. Postgraduate lecturer of brawijaya university.
}

\section{Manuscript Info}

Manuscript History

Received: 02 May 2019

Final Accepted: 04 June 2019

Published: July 2019

Key words:-

coliformic bacteria, drinking water

station, Escherichia coli, Pasuruan regency, water quality .

\begin{abstract}
Escherichia coli is a fecal-coliformic bacteria that usually uses as bioindicator in water quality based on biological parameter. Water source which contaminated with E. coli indicates the contamination of human or mammals feces. This study was aimed to analyze the quality of drinking water stations distributed in Pasuruan Regency. The water samples were collected from the drinking water stations of 24 districts in Pasuruan. The biological parameter of water samples were assayed to detect the coliformic bacteria. Water quality was determined as poor and good quality according to drinking water standard in Indonesia. As a result, most of the drinking water stations from 24 districts in Pasuruan Regency had poor water quality. This happened due to the open defecation behaviour of the social community and lack of sanitation. However, the contamination of coliformic bacteria including E. coli can be reduced by socialization to decrease open defecation behaviour including other behaviour which may decrease the hygiene of environment as well as the drinking water stations. Further, strategy development to get healthy environment is needed.
\end{abstract}

Copy Right, IJAR, 2019,. All rights reserved.

\section{Introduction:-}

Escherichia coli is a Gram negative rod-shaped bacterium that commonly found in the lower intestine of warmblooded organisms (endotherms) including human. It is one of the most frequent causes of many common bacterial infections diseases. According to Elsas et al. [1], E. coli is a commensal bacteria and it has different pathogenic behavior. Their virulence capacity is related to their genes that encode key traits for colonization, secretion of toxic metabolite, transport functions, and invasion. E. coli is the best bacterial indication of fecal contamination in based on the prevalence of thermotolerant coliforms in environment temperature [2].

Java Island is the most dense population in the world, it has more than a thousand people per kilometer square. Pasuruan Regency is an old human settlement area since 10 century in East Java. This area is a representatif of Java Island conditions, it has high land mountain in the south to lowland and also coastal region in the north. Pasuruan consist of 24 districts which total area ranged from 37 to $125.55 \mathrm{~km}^{2}$ and the people were consentrated in urban area that located on lowland and coastal region. People numbers were vary from 18.967 to 131.819 person on each district. 
Inspite of Pasuruan is an old human settlement, it does not mean that people in Pasuruan meets high quality living standard. Some of people have poor behavior such as open defecation. They don't have proper place for defecation such as private house toilet, or communal sanitary facilities. The Faecal contamination of soil and water is common in urban areas due to the overgrowth population, unclean toilets, and the release of waste into the open field without treatment. East Java had $20 \%$ open defecation in 2010 [3]. While WHO 2014 [4], stated that Indonesia had $14 \%$ open defecation people in urban area and $31 \%$ open defecation in rural area. According to Luo et al. [5], there is no difference between E. coli in intestine, in environment, and the calculation of coliform individuals is valid. E. coli which spreading in environment had potential for contaminating household watersource and drinking water station.

Prevalence of E. coli diseases in Pasuruan area was rapidly increase on rainy season. Pasuruan is regularly flooding on heavy rain or continous rain in several days, and E. coli is easily spreading in settlement environment by flood. Pasuruan had six main rivers, e.g., Lawean, Rejoso, Gembong, Welang, Masangan, and Kedunglarangan river. Most of this region were flooded by above rivers especially on lowland area. Worse conditions was happened when the flood brought the organic waste polution into people settlement. These materials could be utilized as nutrient source for bacteria. According to Widmer et al. [6], monitoring urban surface waters for fecal contamination with the possibility of E. coli as an opportunistic pathogen was needed to determine the impact on river waters usage in public health of urban populations in south-east Asia.

Jagals et al. [7] found that the seven genes of invasive and hemorrhagic E. coli strains in the waters. Container had a central role in supplying water to rural communities so further microbiological characterization in water is so much needed. The widespread of E. coli population was poorly recorded and studied in Pasuruan. Rao et al. (2015) found the way to inform community members about the safest locations to get drinking water and watershed scale transport of microbial contaminants/ between villages [8]. Recently, people take the drinking water from drinking water station. Drinking water stations are the key of people health in Pasuruan. It is interesting to detect and analyze E. coli density on drinking water stations in Pasuruan Regency's District. In collaboration with local public health center, this research was aimed to survey and analyze drinking water stations quality in Pasuruan.

\section{Research Purpose:-}

Based on the formulation of the problem above, the objectives of this study are as follows: Analyze the quality of drinking water stations distributed in Pasuruan Regency.

\section{Research Methods:- \\ Data Collection}

The drinking water stations in Pasuruan Regency's District were selected as the sampling locations. There were 24 districts that included in figure 1 and table 1. The water samples were collected from representative area of Pasuruan's districts. The districts were included Bangil, Beji, Gempol, Gondangwetan, Grati, Kejayan, Kraton, Lekok, Lumbang, Nguling, Pandaan, Pasrepan, Pohjentrek, Prigen, Purwodadi, Purwosari, Puspo, Rejoso, Rembang, Sukorejo, Tosari, Tutur, Winongan, and Wonorejo. Each district had different total of water drinking stations (Table 1). However, only water drinking stations that already commercially distributed in market were choosen for its quality analysis in this study.

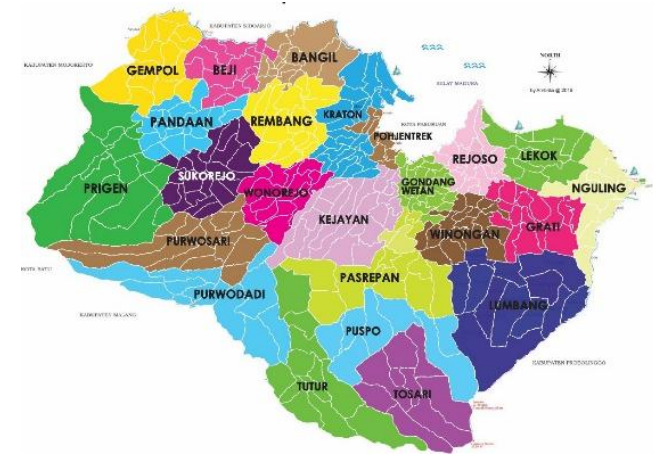

Figure 1. The distribution of 24 districts in Pasuruan 
Table 1:-Total of drinking water stations used for sampling locations

\begin{tabular}{|c|l|c|}
\hline No & \multicolumn{1}{|c|}{ Pasuruan's Districts } & Total of Water Drinking Stations \\
\hline 1 & Bangil & 30 \\
\hline 2 & Beji & 23 \\
\hline 3 & Gempol & 35 \\
\hline 4 & Gondangwetan & 17 \\
\hline 5 & Grati & 19 \\
\hline 6 & Kejayan & 15 \\
\hline 7 & Kraton & 16 \\
\hline 8 & Lekok & 2 \\
\hline 9 & Lumbang & 5 \\
\hline 10 & Nguling & 12 \\
\hline 11 & Pandaan & 37 \\
\hline 12 & Pasrepan & 10 \\
\hline 13 & Pohjentrek & 10 \\
\hline 14 & Prigen & 27 \\
\hline 15 & Purwodadi & 20 \\
\hline 16 & Purwosari & 24 \\
\hline 17 & Puspo & 4 \\
\hline 18 & Rejoso & 12 \\
\hline 19 & Rembang & 3 \\
\hline 20 & Sukorejo & 28 \\
\hline 21 & Tosari & 1 \\
\hline 22 & Tutur & 4 \\
\hline 23 & Winongan & 22 \\
\hline 24 & Wonorejo & 19 \\
\hline & & \\
\hline
\end{tabular}

\section{Water Quality Analysis}

The drinking water quality was analyzed based on the biological parameter standard of drinking water in Indonesia. Firstly, the coliformic bacteria and E. coli in the water samples were counted based on the Most Probable Number (MPN) method in Microbiology Laboratorium. The data obtained were analyzed based on the drinking water quality standard according to Permenkes Nomor 32 Tahun 2017 that the total of coliformic bacteria is $\leq 50 \mathrm{CFU}$ per 100 $\mathrm{mL}$ and the total of E. coli is 0 (zero) CFU per $100 \mathrm{~mL}$ [9]. Therefore, the drinking water quality of each selected stations was categorized as good quality if the standard used was fulfilled and it was categorized as poor quality if the standard used was unfulfilled.

\section{Water Quality Analysis}

The data were analyzed using Microsoft Excel 2007 for Windows. In addition, the quality of the water samples is converted to percentage (\%) to determine the district which has the good quality of drinking water station.

\section{Research Result And Discussion:-}

According to the drinking water standard [9], almost of the selected stations in 24 districts of Pasuruan was varied in the quality (Table 2). Each district has good and poor quality of drinking water stations exclude Lekok and Tosari which only has good quality of drinking water stations. In percent, District of Tosari and Lekok has $100 \%$ good quality of drinking water station followed by District of Kejayan (87\%) and in contrast, District of Rembang has $100 \%$ poor quality of drinking water station (Table 2). 
Table 2:-The drinking water stations quality based on the biological parameters

\begin{tabular}{|c|l|c|c|}
\hline No & Pasuruan's Districts & $\begin{array}{c}\text { Good Quality of Water } \\
\text { Stations }\end{array}$ & Poor Quality of Water Stations \\
\hline 1 & Bangil & 11 & 19 \\
\hline 2 & Beji & 6 & 17 \\
\hline 3 & Gempol & 11 & 24 \\
\hline 4 & Gondangwetan & 7 & 10 \\
\hline 5 & Grati & 7 & 12 \\
\hline 6 & Kejayan & 13 & 2 \\
\hline 7 & Kraton & 9 & 7 \\
\hline 8 & Lekok & 2 & 0 \\
\hline 9 & Lumbang & 2 & 3 \\
\hline 10 & Nguling & 9 & 3 \\
\hline 11 & Pandaan & 16 & 21 \\
\hline 12 & Pasrepan & 4 & 6 \\
\hline 13 & Pohjentrek & 7 & 3 \\
\hline 14 & Prigen & 10 & 17 \\
\hline 15 & Purwodadi & 8 & 12 \\
\hline 16 & Purwosari & 10 & 14 \\
\hline 17 & Puspo & 2 & 2 \\
\hline 18 & Rejoso & 8 & 4 \\
\hline 19 & Rembang & 0 & 3 \\
\hline 20 & Sukorejo & 11 & 17 \\
\hline 21 & Tosari & 1 & 0 \\
\hline 22 & Tutur & 4 & 4 \\
\hline 23 & Winongan & 15 & 7 \\
\hline 24 & Wonorejo & 5 & 14 \\
\hline & & & \\
\hline
\end{tabular}

Although there are two districts that have $100 \%$ good quality of drinking water stations, total of the representative stations in Lekok and Tosari is too slight so that can not be compared to the others which provided with a lot of drinking water stations. However, based on the result, most of the districts could not fulfil the standard quality based on the biological parameters. This can be happened due to several contamination sources from human daily activities or behaviours. The poor quality of drinking water stations is caused by the high contamination of coliformic bacteria including E. coli. The coliformic bacteria is a group of bacteria that naturally living in the digestive tract of human (intestine). The coliformic bacteria are grouped into two groups namely fecal and non-fecal. One of the most important species of fecal-coliformic bacteria is E. coli which usually used as an indicator if the water sources including streams, lakes, etc are contaminated with mammal's feces.

\section{Environmental contamination}

Many pollutan factors could influence the contamination in drinking water. According to Guber et al. [10] the parameters of the survival and release models obtained for E. coli in their study were substantially different from those obtained using other sources, such as domestic animal feces and manures. A comprehensive study is needed to get the better predictions. Yoboue et al. [11] stated that wastewater came from the fish breeding station were potentially pathogenic to human and aquatic organisms because it contained Salmonella, vibrio, Escherishia coli, Staphylococcus and Pseudomonas. In addition, E. coli can contaminate the environment caused by untreated abattoir effluent [12]. Adebayo et al. [13] stated that microorganisms in the environment have different roles such as in sewage, oil treatment, energy generation, oil spillage, and radioactive contamination. Kafle, et al. [14] found in absence of predation and competition, E. coli may be a soil commensal as long as it maintains as stable populations in soil. Jang et al. [15] found that E. coli can be integrated into indigenous microbial communities in the environment. In Ethiopia, Abera et al. [16] found that Bahir Dar was a city with a poor bacterial quality in drinking water. Sachdev et al. [17] stated that water pollutions have great impact on health of society. 


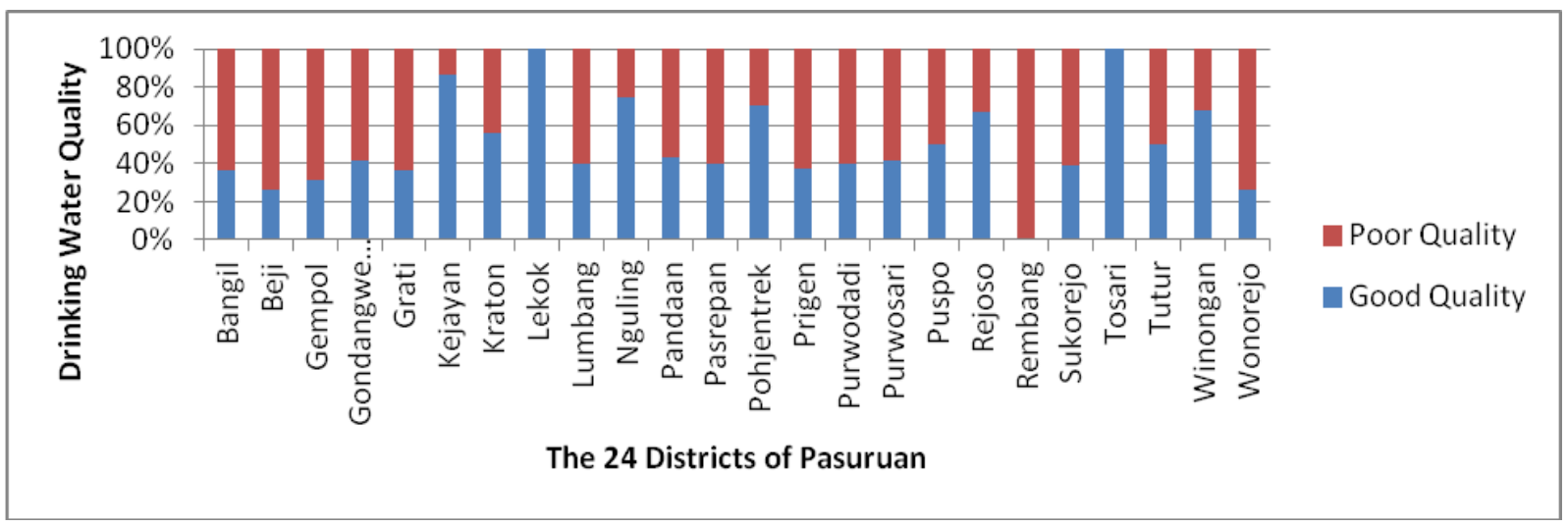

Figure 2:-The percentage of drinking water stations quality in the 24 districts of Pasuruan

According to Villacampa et al. [18], sandy beaches and urban beaches have a higher content of bacteria compared to natural and gravel beaches. This condition is almost the same with Pasuruan regency that have coastal region that potential as a bacterial source. Bok et al. [19] found E. coli isolates from adults have the greater genetic diversity compared to E. coli from young children and constitutes a substantial reservoir of the virulence genes typical for extraintestinal pathogenic E. coli. In urban India, Surya et al. [20] stated that both women and men were use toilets more often during the rainy season. The drop-outs among men were greater than the women in the summer. This case could be happen in Pasuruan.

\section{Possibility of River Watersheed contamination}

River and some water springs in Prigen and Pandaan and also Ranu Grati lake in Grati districts were became the source of drinking water station in Pasuruan and others region. Detecting water of river from E. coli contamination was very important. Some people in Pasuruan still use river as open defecation area. In United States, Lawrence [21] was monitoring river pollution and found that the new set data estimated using regression- 6 on the new Norcross data and regression-12 on the new Atlanta data. It was collected between October 1, 2008 and September 9, 2009. It was matched with measure E. coli densities at the both site using new data. While in China, Sun et al. [22] revealed that the fecal bacteria found in Yangtze River water were highly related with the potential pathogenic bacteria. Fairweather et al. [23] found high multivariate dispersion among downstream samples as well as overall sample dissimilarity that indicated higher heterogeneity downstream. Bussi et al. [24] stated that climate change has no big impact on average river flow and land use change can have a large impact on pathogens.

\section{Good treatement of household equipment and foods}

In this study, it was found that in several drinking water stations were located close to toilets or not separated with toilets. This situation may lead E. coli contamination. A good example was stated by Vannavong et al. [25], that sociodemographic and E. coli contamination in Laos and Thailand were less associated, good treatment of household stored water, regular cleaning of rain jars, and the provision of toilets can inhibit contamination of drinking water. While Wolf et al. [26] suggested that household connections of water supply and higher levels of community were highly supporting the sustainable development goals.

Other important thing was food treatment. Preparing food or food material in properly ways and always do the sanitation of food equipment was important. Nawas et al. [27] found that salad and water in restaurants were contaminated by E.coli in Chittagong Bangladesh. Chekabab et al. [28] also stated that the outbreaks of E. coli O157:H7 in the last decade related to the water contamination and contamination through fresh products (in green leaves and vegetables). Albarri et al. [29] found that E. coli O157:H7 infections for humans can be found in chicken, meat, and vegetables. In order to protect human health, appropriate control measures to eliminate human pathogen should be developed. Oranusi et al. [30] found the microbial loads of the seafood's were more than acceptable standard (significantly higher in gastropods, $\mathrm{p} \leq 0.05$ ). Water body protection and seafood monitoring were necessary.

\section{Escherichia coli Survival}

It is necessary to develop advanced technology to detect E. coli survival in environment. This way is important for Pasuruan environmental health. Ragupathi et al. [31] stated that among the identification methods to differentiate E. 
coli and Shigella serogroups, using single nucleotide polymorphism is easy and among the non-molecular methods matrix-assisted desorption ionization-time of flight mass spectrometry may be applied data analysis is assisted with advanced analytic tools. Adhikari et al. [32] mentioned that E. coli ATCC strains were the longest in response to starvation stress compared to the environmental strains. Environmental isolates didn't show the strong response in the stress condition compared with ATCC strains. Djaouda et al. [33] found bacterial competition to get the nutrients and/or thermolabile antimicrobial substances synthesized by "ultramicrocells" or by the autochthonous bacteria retained by the filter might affect the bacterial survival. E. coli had helped in evolutionary experiments because of its quick environmental adaptation with the rate of cell division once in every $30 \mathrm{~min}$ [34]. While, Singh et al. [35] found high prevalence of antibiotic-resistant commensal E. coli against the commonly used antibiotics among children in Rural Hill Communities of North East India. E. coli effect has some roles in reproductive health and disease [36]. In addition, patients with acute diarrhea under 5 years of age in Myanmar were reported to be very high. Water contaminations in Myanmar were also very high level [37].

\section{Strategic Solution and Mass Desinfection}

The multidimensional indicator framework can provide guidance on monitoring human right to sanitations [38]. Anaerobic baffled reactor (ABR) has been used commonly in Indonesia [39]. The combination of ABR and anammox process in ABR can be potentially become an improvement to remove the nitrogen in ABR. Petrik et al. [40] found that the salinized sea water must be treated with treatment protocols capable of removing both bacterial loads and organic chemical compounds. Drinking water from seawater desalination plants should be carefully tested. They also suggested City of Cape Town to move to an integrated water and sewage management plan. Chubaka et al. [41] stated that households in Adelaide were using domestic filtration to improve municipal water quality. Opposition of water chlorination and fluoridation is not supported by epidemiological evidence showed that these chemicals are harmful. Lewis \& Claasenb [42] suggested the systematic monitoring of groundwater quality, workshops on public health, sanitation practices, and improve sanitation facilities in Namibia. Both desalination sea water treatment as drinking water source and integrated domestic filtration for municipal water treatment were could implemented in Pasuruan. Coastal region of Pasuruan could use desalination sea water and highland or terestrial settlement could use municipal water treatment from ground water or river as drinking water source.

Local government should focus on mass desinfection of drinking water source and improving it. Abhilash \& Harika [43] found solar water disinfection system had arranged the improves of the water quality (free from microbial activity) of drinking water at household level. López et al. [44] mentioned that ultrasound can be implemented as tertiary treatment of municipal wastewater for the removal of biological and organic pollution, according to reuse guidelines in terms of pathogens presence. Bowman et al. [45] found the highly selective affinity towards $\mathrm{Pb} 2+$ observed for strain R19 suggests its use for the recovery of $\mathrm{Pb}^{2+}$ from multiple metal solutions, they were well adapted to unfavorable conditions due to their resistance to metals and antibiotics, so these characteristics may help in developing an effective process for wastewater treatment using these strains. Beltran et al. [46] stated that electing sanitizing products to kill or remove human pathogens from fresh produce to minimize risk of foodborne infections. Antonelli et al. [47] found the toxic effect of Peracetic Acid (PAA) on the aquatic environment was due to the residual disinfectant in the water, rather than to chemical modification of the effluent. Sunil [48] found potential toxic contaminants can be removed more than $95 \%$ by using the reverse osmosis method that has been designed appropriately. Soo-Hwan et al. [49] found Silver nano particles could be used as an effective antibacterial material.

\section{Social Campaign}

Fuller \& Eisenberg [50] stated that understanding the role of herd protection from drinking water, sanitation, and hand hygiene (WASH) interventions can help inform coverage targets and strategies that indirectly protect those that are unable to be reached by WASH campaigns. Abalo et al. [51] prominent people were invited to intermittently grace the National Sanitation Day (NSD) exercise, their invitations should be to empower the local people toesteem the importance of the programme by making it their own rather than depending on their presence to increase patronage.

\section{Conclusion:-}

Drinking water stations in districts of Pasuruan are still remain in poor quality. The coliformic bacteria contamination especially E. coli in drinking water stations is the main problem that cause the quality becomes poor and can not fulfil the drinking water standard according to the biological parameters. Therefore, strategy to reduce the coliformic bacteria including E. coli contamination on drinking water stations is needed to develop for further increase the drinking water quality in Pasuruan Regency of East Java, Indonesia. 


\section{Acknowledgement:-}

We were thanks to Health Department of Pasuruan Regency government. We thanks also to research volunteer from District's Public Health Center for collecting data. In deep thanks also for Head of Districts and Villages for accomodating field trips inspecting the villages environment.

\section{Bibliography:-}

1. Elsas, Jan Dirk van, Alexander V Semenov, Rodrigo Costa, and Jack T Trevors. 2011. The International Society for Microbial Ecology Journal. 5. 173-183.

2. Odonkor, Stephen T., Joseph K Ampofo. 2013. Escherichia coli as an indicator of bacteriological quality of water: an overview. Microbiology Research. 4. 2: 5-11.

3. UNICEF INDONESIA. 2010. Air Bersih, Sanitasi, dan Kebersihan. p.1-6.

4. WHO. 2018. Sanitation. http://www.who.int/topics/sanitation/en/ . Diakses pada 26 November 2018 pukul 10.17 WIB.

5. Luo, Chengwei, Seth T Walk, David M Gordon, Michael Feldgarden, James M Tiedje and Konstantinos T. Konstantinidis. 2011. Genome sequencing of environmental Escherichia coli expands understanding of the ecology and speciation of the model bacterial species. PNAS. 108. 17:7200-7205.

6. Widmer, Kenneth, Nguyen Thi Van Ha, Soydoa Vinitnantharat, Suthipong Sthiannopkao, Setiawan Wangsaatmaja, Maria Angela Novi Prasetiati, Nguyen Cong Thanh, Kasame Thepnoo, Arief Dhany Sutadian, Huynh Thi Thanh Thao, Deby Fapyane, Vibol San, Pierangeli Vital and Hor-Gil Hur. 2013. Prevalence of Escherichia coli in surface waters of Southeast Asian cities. World Journal Microbiology Biotechnology. Springer

7. Jagals, P. T. G. Barnard, M. M. Mokoena, N. Ashbolt and D. J. Roser. 2013. Pathogenic Escherichia coli in rural household container waters. Water Science and Technology. 67. 6:1230-1237.

8. Rao, Gouthami Gabriel Trueba, Joseph N. S. Eisenberg, David G. Kleinbaum, William Cevallos and Karen Levy. 2015. Spatial Variability of Escherichia coli in Rivers of Northern Coastal Ecuador. Water. 7. 818-832.

9. Peraturan menteri kesehatan republik Indonesia.Permenkes No. 32 Tahun 2017.

10. Guber, Andrey K, Jessica Fry, Rebecca L. Ives and Joan B. Rose. 2015. Escherichia coli Survival in, and Release from, White-Tailed Deer Feces. Applied and Environmental Microbiology. 81:1168 -1176.

11. Yoboue, K.P, J.K Coulibaly,B.R Danielle Aboua, S. Berte, N.I Ouattara, M. Dosso, E.P Kouamelan. 2018. Microbiological Quality of Effluents From A Fishing Station Installed At The Edge of The Lagoon Ebrie (Côte d'Ivoire). Journal of Environmental Science, Toxicology and Food Technology. 12. 4.

12. Kabiru, Lawan Mohammed, Mohammed Bello, Junaid Kabir, Laura Grande and Stefano Morabito. 2015. Detection of Pathogenic Escherichia coli in Samples Collected at an Abattoir in Zaria, Nigeria and at Different Points in the Surrounding Environment. International Journal Environmental Research Public Health. 12. 679691.

13. Adebayo, F.O., Obiekezie, S.O. 2018. Microorganisms in Waste Management. Research Journal of Science and Technology. 10, 01.

14. Kafle, G. Nanda, Amy A. Christie1, Sébastien Vilain, Volker S. Brözel. 2018. Growth and Extended Survival of Escherichia coli O157:H7 in Soil Organic Matter. Frontiers in Microbiology, 9.

15. Jang, Jeonghwan Hor-Gil Hur, Michael J. Sadowsky, Muruleedhara N. Byappanahalli, Tao Yan, Satoshi Ishii. 2017. Environmental Escherichia coli: Ecology and Public Health Implications - A Review.

16. Abera, Bayeh, Mulugeta Kibret, Goraw Goshu and Mulat Yimer. 2014. Bacterial quality of drinking water sources and antimicrobial resistance profile of Enterobacteriaceae in Bahir Dar city, Ethiopia. Journal of Water, Sanitation and Hygiene for Development. 4. 3:384-390

17. Sachdev, R., D. Chandra Badhani, S.Pal, N.Sharma. 2018. Study of Differences \& Pathogenicity of Microbial Flora In Various Area at The Bank of Alakanda The Headstream of River Ganga in Srinagar Garhwal, Uttarakhand During Summer Month. International Journal of Scientific Research. 7. 2277-8179.

18. Villacampa, Y., I. Lopez, L. Aragones, C.Garcia, M. Lopez, A. Palazon. 2017. Water Quality of the Beach in an Urban and Not Urban Environment. International Journal of Sustainable Development and Planning. 12. 4: 713723.

19.Bok, Ewa, Justyna Mazurek, Andrzej Myc, Michał Stosik, MagdalenaWojciech, Katarzyna Baldy-Chudzik. 2018. Comparison of Commensal Escherichia coli Isolates from Adults and Young Children in Lubuskie Province, Poland: Virulence Potential, Phylogeny and Antimicrobial Resistance. International Journal Of Environmental Research and Public Health. 15. 617. 
20. Surya, A V , Archna Vyas, Madhu Krishna, Naseem Abidi. 2017. Identifying Determinants of Toilet Usage by Poor in Urban India. Procedia Computer Science. 122. 634-641.

21.Lawrence, S.J., 2012, Escherichia coli bacteria density in relation to turbidity, streamflow characteristics, and season in the Chattahoochee River near Atlanta, Georgia, October 2000 through September 2008-Description, statistical analysis, and predictive modeling: U.S. Geological Survey Scientific Investigations Report 2012-5037, 81

22. Sun, Haohao Xiwei He, Lin Ye, Xu-Xiang Zhang, Bing Wu, and Hongqiang Ren. 2016. Diversity, abundance, and possible sources of fecal bacteria in the Yangtze River. Applied Microbiology Biotechnology. Springer. 110.

23. Fairweather, Peter G., Lisa M. Dann, Renee J. Smith, Thomas C. Jeffries, Jody C. McKerral, Rod L. Oliver and James G. Mitchell. 2016. Persistence, loss and appearance of bacteria upstream and downstream of a river system Marine and Freshwater Research. CSIRO Publishing. 1-12.

24. Bussi, Gianbattista, Paul G. Whitehead, Amy R.C. Thomas, Dario Masante, Laurence Jones, B. Jack Cosby, Bridget A. Emmett, Shelagh K. Malham, Christel Prudhomme and Havard Prosser. 2017. Climate and land-use change impact on faecal indicator bacteria in a temperate maritime catchment (the River Conwy, Wales). Journal of Hydrology.

25. Vannavong, N., H. J. Overgaard, T. Chareonviriyaphap, N. Dada, R. Rangsin, A. Sibounhom, T. A. Stenström and R. Seidu. 2017. Assessing factors of E. coli contamination of household drinking water in suburban and rural Laos and Thailand. Water Science \& Technology: Water Supply. 1-16.

26. Wolf, Jennyfer, Paul R. Hunter, Matthew C. Freeman, Oliver Cumming, Thomas Clasen, Jamie Bartram, Julian P. T. Higgins, Richard Johnston, Kate Medlicott, Sophie Boisson, Annette Prüss-Ustün. 2018. Impact of Drinking Water, Sanitation and Hand Washing with Soap on Childhood Diarrhoeal Disease : Updated Meta Analysis and - Regression. Tropical Medicine \& International Health.

27. Nawas T, R. M. Mazumdar, S. Das, M. N. Nipa, S. Islam, H. R. Bhuiyan and I. Ahmad. 2012. Microbiological Quality and Antibiogram of E. coli, Salmonella and Vibrio of Salad and Water from Restaurants of Chittagong. J. Environ. Sci. \& Natural Resources. 5. 1: 159 - 166.

28. Chekabab, Samuel Mohammed, Judith Paquin-Veillette, Charles M. Dozois \& Josee Harel. 2013. The ecological habitat and transmission of Escherichia coli O157:H7. Federation of European Microbiological Societies Microbiology Letters. 341. 1-12.

29. Albarri, Osman, Iş̧1 Var, Melda Meral,Başak bedir, Behzad Heshmati ,FatihKöksal. 2017. Prevalence of Escherichia coli isolated from meat, chicken and vegetable samples in Turkey. Journal of Biotechnology Science Research. 4. 3:214-2022.

30. Oranusi , S.,Effiong, E. D.,Duru, N. U. 2018. Comparative Study of Microbial, Proximate, and Heavy Metal Compositions of Some Gstropods, Bivalve, and Crustacean Foods. African Journal of Clinical and Experimental Microbiology. 14. 4.

31. Ragupathi, N. K. Devanga, D. P. Muthuirulandi Sethuvel, F. Y. Inbanathan, B. Veeraraghavan. 2017. Accurate differentiation of Escherichia coli and Shigella serogroups: challenges and strategies. New Microbe and New Infect Elsevier. 21: 58-62.

32. Adhikari, Achyut, Andy Bary, Craig Cogger, Caleb James, Gulhan Unlu, and Karen Killinger. 2016. Thermal and Starvation Stress Response of Escherichia coli O157:H7 Isolates Selected from Agricultural Environments. Journal of Food Protection. 79. 10:1673-1679

33. Djaouda, Moussa, Bouba Gaké, Daniel Ebang Menye, Serge Hubert Zébazé Togouet and Moise Nola. 2013. Survival and Growth of Vibrio cholerae, Escherichia coli, and Salmonella Spp. in Well Water Used for Drinking Purposes in Garoua (North Cameroon). Hindawi Publishing Corporation International Journal of Bacteriology. 2013. 127179.

34. Taj, Muhammad Kamran, Zohra Samreen, Ji Xiu Ling, Imran Taj,Taj Muhammad Hassani and Wei Yunlin. 2014. Escherichia coli as a model organism. International Journal of Engineering Research and Science \& Technology. 3. 2: 1-11.

35. Singh, Ashish Kumar, Saurav Das, Samer Singh, Varsha Rani Gajamer, Nilu Pradhan, Yangchen Doma Lepcha,Hare Krishna Tiwari. 2018. Prevalence of Antibiotic Resistance in Commensal Escherichia Coli among the Children in Rural Hill Communities of North East India. BioRxiv.

36. Cools, Piet, 2017. The role of Escherichia coli in reproductive health: state of the art. Research in Microbiology xx Elsevier. 1-10.

37. Myint, Su Latt Tun, Thazar Myint, Wah Wah Aung and Khin Thet Wai. 2015. Prevalence of household drinkingwater contamination and of acute diarrhoeal illness in a periurban community in Myanmar. WHO SouthEast Asia Journal of Public Health. 4. 1-7. 
38. Giné-Garriga, R., Óscar Flores-Baquero, Alejandro Jiménez-Fdez. de Palencia,Agustí Pérez-Foguet. 2016. Monitoring Sanitation and Hygiene in The 2030 Agenda for Sustainable Development: A Review Through the Lens of Human Rights. Science of The Total Environment. 580. 1108-1119.

39. Wijaya, I Made Wahyu Eddy Setiadi Soedjono. 2018. Domestic Wastewater in Indonesia : Challenge in The Future Related To Nitrogen Content. International Journal of GEOMATE. 15, 47.

40. Petrik, Leslie Lesley Green, Adeola P. Abegunde, Melissa Zackon, Cecilia Y. Sanusi and Jo Barnes. 2017. Desalination and seawater quality at Green Point,Cape Town: A study on the effects of marine sewage outfalls. South African Journal of Science. 113. 11/12: 1-10.

41. Chubaka, Chirhakarhula E., Kirstin E. Ross, Johm W. Edwards. 2017. Rainwater for drinking water: A study of household attitudes. WIT Transactions on Ecology and The Environment. 216.

42. Lewis E., and T. Claasenb. 2018. Monitoring Groundwater Quality in a Namibian Rural Settlement. Water Practice \& Technology. 13.2.

43. Abhilash, N., and B. Harika. 2018. Purification and Disinfection of Water by Solar Energy. International Journal of Current Engineering and Scientific Research (IJCESR). 5. 5.

44.López, Monserrat Vázquez, Leonel Ernesto Amabilis Sosa, Gabriela Eleonora Moeller Chávez, Adriana Roé Sosa, Patricio Neumann \& Gladys Vidal .2018. Evaluation of the ultrasound effect on treated municipal wastewater. Environmental Technology.

45. Bowman, Nichole, Drashti Patel,Alysia Sanchez,Wentao XU, Ali Alsaffar ,Sonia M. Tiquia-Arashiro. 2018. Lead-resistant bacteria from Saint Clair River sediments and $\mathrm{Pb}$ removal in aqueous solutions. Applied Microbiology and Biotechnology. 102:2391-2398.

46. Beltran, Marcela Soto, Maribel Jimenez Edeza, Celina Viera, Celida I. Martinez ,Cristobal Chaidez .2012. Sanitizing alternatives for Escherichia coli and Salmonella typhimurium on Bell Peppers at Household Kitchens, International Journal of Environmental Health Research,1-11.

47. Antonelli, M., A. Turolla, V. Mezzanotte and C. Nurizzo. 2013. Peracetic Acid for Secondary Effluent Disinfection: A Comprehensive Performance Assessment. Water Science \& Technology. 68.12.

48. Sunil J. 2013. Purification of Contaminated Water with Reverse Osmosis: Effective Solution of Providing Clean Water for Human Needs in Developing Countries. International Journal of Emerging Technology and Advanced Engineering. 3. 12.

49. Soo-Hwan, Kim, Hyeong-Seon Lee, Deok-Seon Ryu, Soo-Jae Choi, Dong-Seok Lee. 2011. Antibacterial Activity of Silver-nanoparticles Against Staphylococcus aureus and Escherichia coli. Korean Journal of Microbiology and Biotechnology. 39. 1: 77-85.

50. Fuller, James A., Joseph N. S. Eisenberg. 2016. Herd Protection from Drinking Water, Sanitation, and Hygiene Interventions. The American journal of tropical medicine and hygiene.

51. Abalo, Emmanuel Mawuli, Seth Agyemang, Samuel Atio, Derrick Ofosu-Bosompem, Prince Peprah,Rita Ampomah-Sarpong. 2017. Environmental sanitation unleashed: Effectiveness and challenges of the National Sanitation Day as a community sanitation participatory approach in Aboabo, Ghana. Cogent Environmental Science. 3: 1405888. 